\title{
AVALIAÇÃO SOROLÓGICA DA VACINA ORAL, TIPO SABIN, CONTRA A POLIOMIELITE, EM REGIĨO SEMI-RURAL: I. FORMAÇÃO DE ANTICORPOS EM VACINADOS *
}

\author{
Schatzmayr, H. G. ** e Homma, A. ***
}

Os autores descrevem os resultados obtidos em um programa de avaliação sorológica da vacina oral, tipo Sabin, contra a poliomielite, em uma comunidade semi-rural, próxima a cidade do Rio de Janeiro. Em condições controladas 114 crianças, com idades entre 3 meses a 3 anos (Tabela 1) foram vacinadas, com vacinas trivalentes $\left(500.000,200.000\right.$, e $300.000 T C D_{50}$ por dose, dos tipos 1, 2 e 3 respectivamente), usando-se três doses, com intervalos de 8 semanas entre as doses.

Amostras de sangue foram coletadas por punção venosa ou discos de papel de filtro, juntamente com a $1 .^{a}$ e $a 3^{a}$ dose de vacina e 9 semanas após esta última dose de vacina.

As taxas de conversão alcançaram (diluiçẫo de sôro 1/8) $82,7 \%, 98,5 \%$ e 75,4\% para os tipos 1, 2 e 3 respectivamente, após três doses de vacina (Tabela $\mathfrak{2}$ ).

A distribuição de idade de indivíduos sem anticorpos após a vacinação (Tabela 3) mostra o grupo etário de 1 a 2 anos como o que apresenta a mais baixa taxa de conversão.

Os autores acentuam que as condições de vida da população restudada correspondem àquelas de grandes partes da população brasileira, nas áreas rurais do pais; e uma avaliaçấo semelhante da vacina em áreas urbanas, seria desejável.

Os autores sugerem ainda o aumento da quantidade de vírus do tipo 1 na vacina como medida provàvelmente eficaz na melhora das taxas de conversão em populações como a estudada.

Estudos quantitativos sôbre anticorpos para Enterovírus, presentes na população estudada, estão sendo realizados e serão pròximamente apresentados.

$\hat{E}$ fato bem conhecido que a aplicação da vacina oral contra a poliomielite, tipo Sabin, em clima temperado tem alcançado resultados satisfatórios, inclusive com pràticamente a erradicação da doença. Em paises tropicais porém, os resultados tem sido freqüentemente desapontadores. Diversas razões devem influenciar neste fato ,além das dificuldades de manutenção de esquemas de vacinação rígidos, alcançando a população infantil susceptível, em percentagens necessárias ao contrôle da infecção natural.

Pareceu-nos útil proceder a uma vacinação em condições controladas e verificar qual a resposta imunitária que se deve esperar, em uma área semi-rural, próxima a núcleos urbanos.

\footnotetext{
* Trabalho do Departamento de Ciências Blológicas, Laboratório de Enterovirus Fundação Ensino Especializado de Saúde Pública (FENSP), Caixa Postal, 16 - ZC - 24 - Rio de Janeiro, Brasil.

* Professor-Adjunto e responsável pelos Laboratórios de Vírus da FENSP.

** Virologista do Departamento de Ciências Biológicas da FENSP.
} 


\section{MATERIAL E MÉTODOS}

1) - População estudada - Foram vacinadas crianças entre 3 meses e 3 anos de idade, no município de Magé, distante cêrca de $50 \mathrm{~km}$ da cidade do Rio de Janeiro. A maioria das crianças pertencia a famílias de operários de uma fábrica de tecidos, a qual presta assistência médica através de um Pôsto de Saúde, onde foi possivel organizar a vacinação. O nível sócio-econômico da população era razoável, via de regra, com algumas famílias dispondo de melhores condições, inclusive de moradia.

2) - Vacinas empregadas: Usaram-se vacinas trivalentes, contendo $500.000, \ldots$. 200.000 e 300.000 TCD por doses, dos tipos 1,2 e 3 respectivamente (Institute of Poliomyelitis - Moscow, Serial N.o 363).

As vacinas foram aplicadas com conta-gôtas sob estrito contrôle e titulações realizadas antes e após o trabalho mostraram que as vacinas haviam mantido o título original. Foram aplicadas três doses de vacina, com intervalos de 8 semanas e as coletas de sangue foram realizadas junto com a $1 .^{\mathrm{a}}$ e a $3 .^{\mathrm{a}}$ dose de vacina e finalmente 9 semanas após a última dose.

3) - Esquema de coleta de material: As crianças foram escolhidas entre aquelas que ocorreram a vacinação, dentro do grupo etário fixado, colhendo-se sangue por punção venosa ou por meio de discos de papel de filtro (Carl Schleicher \& Schuell, Co. $\phi 12,7 \mathrm{~mm}, \mathrm{n} .{ }^{\circ} 740$ - E) neste último caso na regiāo do calcanhar, após lesão puntiforme na região. Das amostras de sangue foram separados os sôros e congelados a menos $15^{\circ} \mathrm{C}$; os discos saturados de sangue foram acrescentados de meio Eagle com antibióticos, de maneira a se obter diluiçóes de 1/8. Prèviamente foram avaliadas as quantidades de líquido absorvido pelo disco e para maior exatidāo foram determinados os valôres de hematócrito na população. Os discos, suspensos em meio, foram agitados durante $10 \mathrm{mi}-$ nutos e deixados, uma noite, a 4-6 ${ }^{\circ}$, para perfeita eluição, após o que foram descartados e os tubos centrifugados a $1.500 \mathrm{rpm}$ por 10 minutos.

4) - Determinação dos anticorpos: Foram usadas microtécnicas (1) tendo como antígenos as amostras Mahoney, Lansing e Leon, dos tipos 1, 2 e 3 respectivamente, a células H.Ep.2, crescendo em meio de Eagle modificado (4) com adição de triptose fosfato e $2 \%$ de sôro de galinha, mais Penicilina, Estreptomicina e Fungizone.

As misturas sôro-vírus foram incubadas a $37^{\circ} \mathrm{C}$ por uma hora e finalmente por uma noite a $4-6^{\circ} \mathrm{C}$. As células foram observadas em microscópio invertido, por uma semana antes da leitura final, usando-se $100 \mathrm{TCD}_{50}$ de cada vírus nas provas.

Consideram-se como conversão os sôros com títulos iguais ou superiores a $1 / 8$, e que foram negativos $(<8)$ em coletas anteriores.

\section{RESULTADOS}

O esquema de vacinação e coleta de sangue foi completado em 114 crianças distribuídas segunda a tabela 1 no grupo etário escolhido.

Verificamos que 32 crianças apresentavam-se triplo negativas quando da $1 .^{\mathrm{a}} \mathrm{co}$ leta $(28 \%)$ enquanto $20(17 \%)$ já haviam completado sua imunização natural.

TABELA 1

Distribuição de ldade das Crianças estudadas

\begin{tabular}{|c|c|c|c|}
\hline Idade & Distribuição Total & $\begin{array}{c}\text { Triplo Negativo } \\
\text { (1. a Coleta) }\end{array}$ & $\begin{array}{l}\text { Triplo positivo } \\
\text { (1. }{ }^{\mathrm{a}} \text { Coleta) }\end{array}$ \\
\hline $\begin{array}{ll}1 \text { a } 2 \text { ano } \\
2 \text { anos } \\
2 \text { anos }\end{array}$ & $\begin{array}{l}14 \\
31 \\
69\end{array}$ & $\begin{array}{l}10 \\
10 \\
12\end{array}$ & $\begin{array}{r}1 \\
5 \\
14\end{array}$ \\
\hline TOTAL & 114 & 32 & 20 \\
\hline
\end{tabular}


Em titulações de anticorpos comparativas em amostras de sangue colhidas por punção venosa e por discos de papel de iltro, Liss mesmos indivíduos, obtiveram-se títulos idênticos, de maneira reproduzível, com as técnicas aqui descritas. Dêste modo, os títulos obtidos são comparados, sem distinção do método de coleta.

$\mathrm{Na}$ tabela 2 são apresentados os resultados das determinaçōes da presença de anticorpos antes e após as vacinações, duas e três doses respectivamente.
Para uma melhor avaliação, são separados os sôros em relação às amostras de Poliovírus para as quais não foram demonstrados anticorpos na $1 .^{\text {a }}$ coleta de sangue realizada. Verifica-se nos totais a falta de conversão após duas e três doses de vacina respectivamente.

A distribuição por idade das crianças sem anticorpos após as vacinações é apresentada na tabela 3 , em relação aos respectivos tipos de Poliovírus para os quais anticorpos não foram detectados.

\section{TABELA 2}

Distribuiçâo dos sôros sem anticorpos $(<8)$, antes $e$ após a vacinação oral, tipo Sabin, trivalente em relação aos tipos de Poliovirus

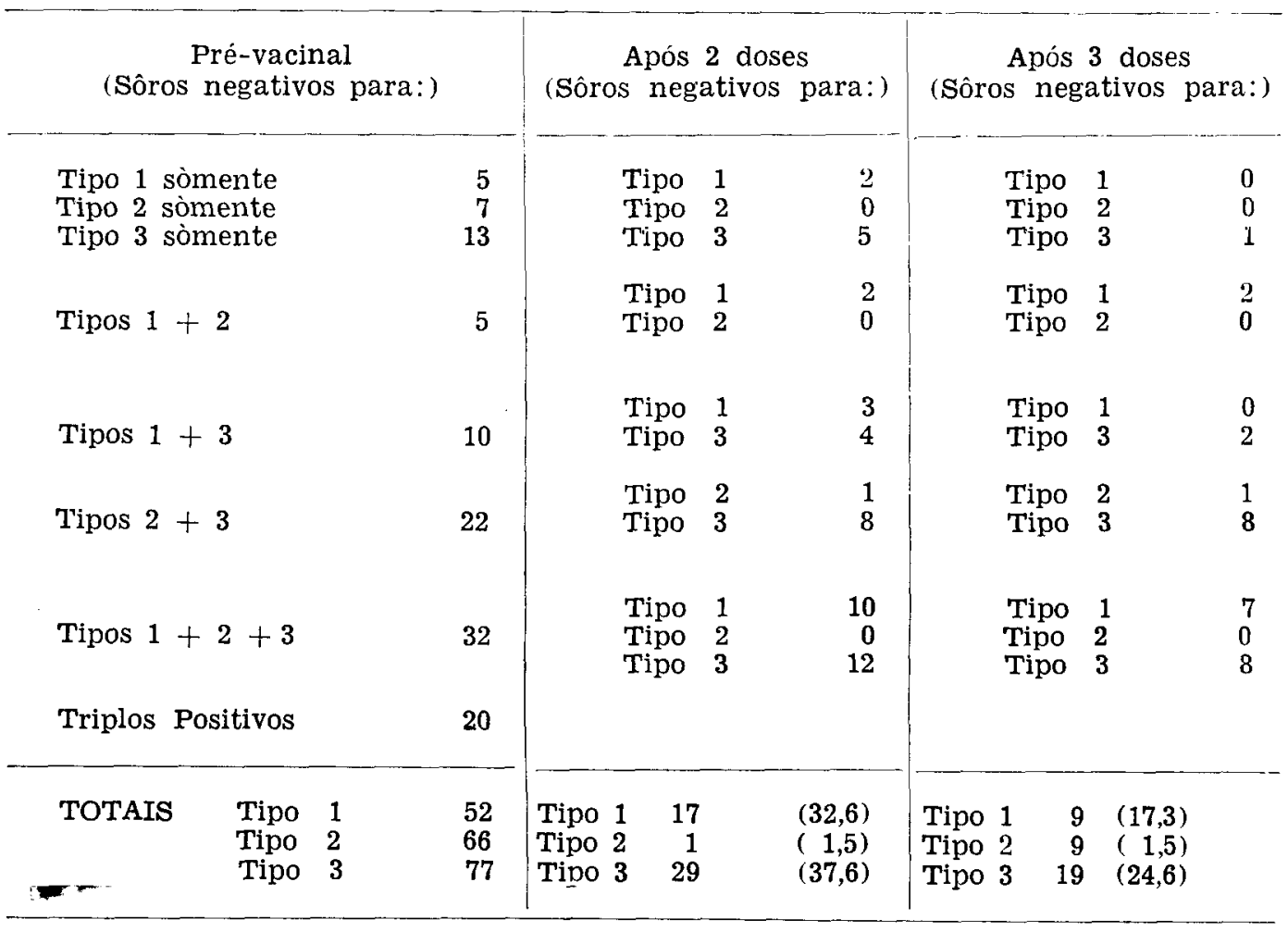

( ) $=\%$ de relação aos totais respectivos.

\section{DISCUSSÃO}

A ocorrência de Enterovírus na cidade do Rio de Janeiro e cidades vizinhas tem sido acompanhada por nosso grupo de trabalho, através tentativas de isolamento de vírus de casos suspeitos de poliomielite $(5,6,7,9)$ e entre êstes, foram encontradas algumas crianças com duas e até três doses de vacina contra a poliomielite. Principalmente êstes casos nos levaram a planejar e desenvolver o trabalho aqui descrito.

A coleta de sangue em papel de filtro com a finalidade de facilitar estudos sorológicos, especialmente em crianças, tem sido usada por diversos autores especialmente para Enterovírus $(1,2,3)$. Utilizamos neste trabalho coletas em papel de filtro ou punção venosa, com microtécnicas de titulação de anticorpos. Materiais colhidos por um ou outro método, demons." 
traram idênticos títulos em testes comparativos executados prèviamente. Êstes resultados comparativos nos permitiram usar um ou outro método de coleta, de acôrdo com as possibilidades de trabalho. A coleta por papel de filtro foi decidida, quando da recusa por parte dos responsáveis pelas crianças, da coleta por punção venosa.

Na tabela I verificamos uma distribuição uniforme dos triplos negativos pelos três grupos de idade e pelo exame dos triplos positivos, a indicação que a população estudada completou seu processo de imunização natural, principalmente após - $2^{\circ}$ ano de vida. $\mathrm{Na}$ ocasião dos estudos aqui descritos, não foram observados casos clínicos de poliomielite na região, embora êstes tenham sido assinalados anteriormente (6) acompanhando uma onda epidêmica da cidade do Rio de Janeiro em 1965.

Em relação à conversão, ou seja o aparecimento de anticorpos em crianças prèviamente negativas, (Tabela 2) observamos uma excelente resposta para o tipo 2 da vacina, pois apenas uma criança em 66, não veio a formar anticorpos. Poliovírus do tipo 2 já foi demonstrado como principal responsável por epidemias na re- gião (6) com taxa de mortalidade de cêrca de $10 \%$. Quanto ao tipo 1 a percentagem de 17,3 de falhas na imunizaçāo, parece-nos acima do que seria desejado, considerando-se ter sido o tipo 1 o principal responsável por quadros clínicos de poliomielite, na maioria das vêzes em que forma feitas tentativas de isolamento na área estudada $(7,9)$.

Quanto ao tipo 3 tivemos a mais baixa conversão dos três tipos.

$O$ tipo 3 tem surgido esporàdicamente, especialmente em períodos epidêmicos (6), isolado de casos clínicos.

$\mathrm{Na}$ Tabela 3 são apresentados os indivíduos não-convertores, em relação à idade; o grupo entre 1 e 2 anos aparece como o que apresenta mais baixa conversão e esta faixa de idade corresponde exatamente àquela com maior número de casos paralíticos na região $(6,7,9)$.

Uma maior quantidade de vírus do tipo 1 parece-nos essencial para obtermos uma melhor resposta imunitária para êste tipo, em condições semelhantes às aqui estudadas. Esta hipótese poderia ser confirmada, por meio de um trabalho de avaliação sorológico.

O grupo populacional onde realizamos êste trabalho representa por seu tipo de

\section{TABELA 3}

Distribuiçâo por idade dos individuos sem anticorpos $(<8)$ após vacinação oral tipo Sabin, trivalente, contra Poliomielite

\begin{tabular}{|c|c|c|c|c|c|c|c|c|}
\hline Idade & \multicolumn{4}{|c|}{$\begin{array}{c}\text { Após } 2 \text { doses } \\
\text { (Sôros negativos para:) }\end{array}$} & \multicolumn{4}{|c|}{$\begin{array}{l}\text { Após } 3 \text { doses } \\
\text { (Sôros negativos para:) }\end{array}$} \\
\hline$<1$ ano & $\begin{array}{l}\text { Tipo } \\
\text { Tipo } \\
\text { Tipo }\end{array}$ & $\begin{array}{l}1 \\
2 \\
3\end{array}$ & $\begin{array}{l}4 \\
1 \\
5\end{array}$ & $\begin{array}{r}(25,5) \\
(100) \\
(17,3)\end{array}$ & $\begin{array}{l}\text { Tipo } \\
\text { Tipo } \\
\text { Tipo }\end{array}$ & $\begin{array}{r}1 \\
2 \\
3\end{array}$ & $\begin{array}{l}2 \\
1 \\
4\end{array}$ & $\begin{array}{r}(22,2) \\
(100) \\
(21,1)\end{array}$ \\
\hline 1 a 2 anos & $\begin{array}{l}\text { Tipo } \\
\text { Tipo } \\
\text { Tipo }\end{array}$ & $\begin{array}{l}1 \\
2 \\
3\end{array}$ & $\begin{array}{r}8 \\
0 \\
13\end{array}$ & $\begin{array}{l}(47,0) \\
(44,8)\end{array}$ & $\begin{array}{l}\text { Tipo } \\
\text { Tipo } \\
\text { Tipo }\end{array}$ & $\begin{array}{l}1 \\
2 \\
3\end{array}$ & $\begin{array}{r}5 \\
0 \\
11\end{array}$ & $\begin{array}{l}(55,6) \\
(57,8)\end{array}$ \\
\hline$>2$ anos & $\begin{array}{l}\text { Tipo } \\
\text { Tipo } \\
\text { Tipo }\end{array}$ & $\begin{array}{l}1 \\
2 \\
3\end{array}$ & $\begin{array}{r}5 \\
0 \\
11\end{array}$ & $\begin{array}{l}(29,5) \\
(37,9)\end{array}$ & $\begin{array}{l}\text { Tipo } \\
\text { Tipo } \\
\text { Tipo }\end{array}$ & $\begin{array}{l}1 \\
2 \\
3\end{array}$ & $\begin{array}{l}2 \\
0 \\
4\end{array}$ & $\begin{array}{l}(22,2) \\
(21,1)\end{array}$ \\
\hline TOTAIS & $\begin{array}{l}\text { Tipo } \\
\text { Tipo } \\
\text { Tipo }\end{array}$ & $\begin{array}{l}1 \\
2 \\
3\end{array}$ & $\begin{array}{r}17 \\
1 \\
29\end{array}$ & & $\begin{array}{l}\text { Tipo } \\
\text { Tipo } \\
\text { Tipo }\end{array}$ & $\begin{array}{l}1 \\
2 \\
3\end{array}$ & $\begin{array}{r}9 \\
1 \\
19\end{array}$ & \\
\hline
\end{tabular}


vida semi-rural, aquelas condições que encontramos em grandes partes da população brasileira. Esperamos realizar com fins comparativos trabalho semelhante em populações urbanas.

$\mathrm{Na}$ área estudada a vacina oral Sabin não havia sido introduzida em escala significativa desde 1965; muito provàvelmente não tiveram as crianças incluídas nesta avaliação qualquer contacto com o vírus da poliomielite atenuada nem mesmo sob a forma de contágio familiar. A vacina do tipo Salk também não foi usada na comunidade.

O período dos estudos aqui descritos iniciou-se nas épocas mais frias do ano; dados sôbre a distribuição sasonal de enterovírus na região estudada, que nos permitam dizer sôbre a influência do clima na implantação de amostras vacinantes de Poliovírus, não são ainda disponíveis. Estudos quantitativos sôbre os anticorpos para Enterovírus apresentados pela populaçāo vacinada, estão sendo realizados e serão objeto de próxima comunicaçāo.

\section{AGRADECIMENTOS}

Os autores agradecem a todos que colaboraram na coleta do material e nos trabalhos de laboratório em particular a Biologista Maria Lucilia Loureiro e aos Drs. Guayr de Oliveira e Júlio de Araújo Mesquita, todos da F.E.N.S.P. Agradecem ainda ao Dr. J. L. Melnick (Baylor University, Houston, Texas, U.S.A.) pela gentileza do envio dos sôros padrões usados neste trabalho.

\section{$S U M A M R Y$}

The authors describe an evaluation programm of Sabin oral vaccine against Poliomyelitis in a semi-rural community, about $50 \mathrm{Km}$ away from Rio de Janeiro.

114 children (age between 3 months to 3 years) have been vaccinated (Table 1) with trivalent vaccines $\left(500.000,200.000\right.$ and 300.000 TCD $D_{50}$ per dose for type 1, 2 and 3 respectively) in a total of three doses, with 8 weeks intervals.

Blood samples have been collected by venous puncture or filter paper discs, by the first and the third dose and 9 weeks after this third dose. The conversion rate obtained (serum dilution $1 / 8$ ) reached $82,7 \%$ for type $1,98,5 \%$ for type 2 and 75,4\% for type 3 (Table 2), after 3 doses of vaccine.

The age distribution of the children without antibodies, after 3 doses of vaccine (Table 3) shows that the age group between 1 and 2 years presents the worse conversion rate.

It is pointed out that the life conditions of the studied population are similar to the ones in the rural parts of the country; a comparative evaluation in a urban area woud be very desirable.

The authors suggest that the increase of the amount of Poliovirus type 1, present in the vaccine, most probably would improve the conversion rates in populations like in this paper.

Quantitative studies about Enterovirus antibodies in the studied population will be presented later.

\section{BIBLIOGRAFIA}

1. CHIN, J., SCHMIDT, N.J., LENNETTE, E.H. \& HANAHOE, M., - Filter paper disc method of collecting whole blood for serologic studies in children, Amer. J. Epidem. 84: 74-80, 1966

2. FARREL, L.N. \& REID, D.B.W. Disc-plate assay of poliomyelitis antibodies, Canad. J. Publ. Hlth. 50: 20-26 1959
3. GREEN, R.H., \& OPTON E.M. - A micromethod for determination of poliovirus antibody suitable for mass surveys, Amer. J. Hyg. 72: 195-203 1960

4. MACPHERSON, T., \& STOKER, M., Polyoma transformation of hamster cell clones an investigation of genetic factors affecting cell competence, Virology 16: $147-1511962$ 
5. SCHATZMAYR, H.G. \& COSTA, L.T., - Isolamento do vírus da poliomielite a partir de material de garganta $\mathrm{em}$ uma comunidade rural, Bol. Inst. Puer. Univ. Brasil 22: 135-138 1965

6. SCHATZMAYR, H.G., \& COSTA L. T., - Estudos sôbre poliomielite na Guanabara: predominância do tipo 2 em casos de paralisia, Bol. Int. Puer. e Pep. M.G., 23: 38-42 1966

7. SCHATZMAYR, H.G., \& VILLASBOAS, D.M., - Poliovirus Tipo $1 \mathrm{em}$ casos de poliomielite aguda no Esta- do da Guanabara, Rev. Inst. Med. Trop., 8: 246-248 1966

8. SULLIVAN, E.J. \& ROSENBAUM, M. J., - Methods for preparing tissue culture in disposable microplates and their use in virology, Am. J. Epidem. 85: $424-4371967$

9. VON HUBINGER, M.G., VILLASBOAS, D.M. \& \& SCHATZMAYR, H.G., - Estudo sôbre casos de poliomielite aguda no Estado da Guanabara, O Hospital, 71: 991-994 1967 